\section{Brown tumors of the femur and pelvis secondary to a parathyroid carcinoma. Report of one case}

\author{
DAN RADULESCU ${ }^{1}$, BOGDAN CHIS ${ }^{2}$, \\ VALER DONCA ${ }^{3}$, VALENTIN MUNTEANU ${ }^{4}$
}

\begin{abstract}
Brown tumors result from excess osteoclast activity and consist of collections of osteoclasts intermixed with fibrous tissue and poorly mineralized woven bone. They are secondary to hyperparathyroidism (HPT). Their incidence is higher in primary than in secondary hyperparathyroidism. We report a 69 years-old male, admitted in a state of confusion, lethargy and bedridden, with a pathological fracture of the femur caused by a brown tumor. The laboratory examination revealed a hypercalcemia $(8.85 \mathrm{mEq} / \mathrm{L})$, with high levels of ionized $\mathrm{Ca}$ $(5.48 \mathrm{mEq} / \mathrm{L})$, serum alkaline phosphatases $(416 \mathrm{U} / \mathrm{L})$ and serum parathormone $(120 \mathrm{pg} / \mathrm{mL})$. Ultrasound examination of the neck showed a large parathyroid tumor, probably corresponding to a carcinoma. A primary HPT was diagnosed. The patient was hydrated and high doses of diuretics and bisphosphonates were administered. After correction of serum calcium and neurologic symptoms, the patient was operated, performing an extensive resection of the tumor. The pathology report confirmed the diagnosis of parathyroid carcinoma.
\end{abstract}

(Rev Med Chile 2014; 142: 919-923)

Key words: Hypercalcemia; Hyperparathyroidism; Parathyroid neoplasms.

\section{Tumores pardos de fémur y pelvis secundarios a carcinoma de paratiroides. Informe de un caso}

Los tumores pardos son una consecuencia de una actividad osteoclástica excesiva y consisten en osteoclastos mezclados con tejido fibroso y tejido óseo mal mineralizado. Son secundarios a hiperparatiroidismo y más comunes en hiperparatiroidismo primario. Informamos de un hombre de 69 años que ingresa confuso y letárgico con una fractura patológica del fémur causada por un tumor pardo. El laboratorio mostró hipercalcemia de $8,85 \mathrm{mEq} / \mathrm{L}$, fosfatasas alcalinas de $416 \mathrm{U} / \mathrm{L}$ y parathormona de $120 \mathrm{pg} / \mathrm{mL}$. La ecografía del cuello mostró un tumor paratiroideo sospechoso de carcinoma. Se diagnosticó un hiperparatiroidismo primario. El paciente se hidrató y estabilizó con diuréticos y bifosfonatos. Una vez estabilizado, se operó efectuando una extensa resección del tumor. El estudio anatomopatológico confirmó el diagnóstico de cáncer de paratiroides.

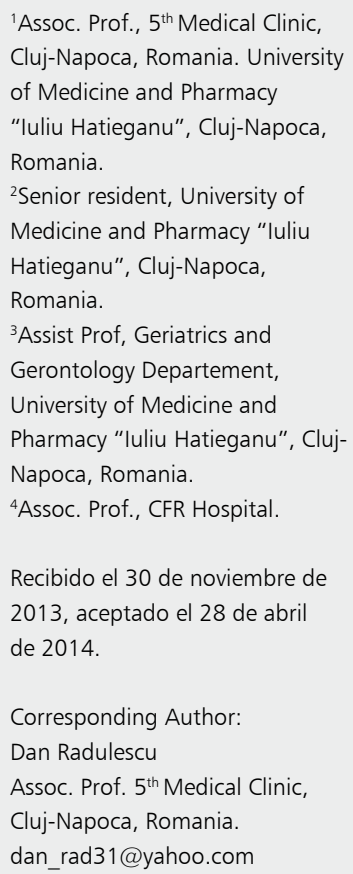

$\mathrm{P}$ arathyroid carcinoma (PTC) is a very rare malignant tumor, its incidence being $0.35-0.57$ in 1 million individuals ${ }^{1}$. Most of the PTC are secretory, with very high serum $\mathrm{PTH}$ and calcium. One complication of primary hyperparathyroidism (HPT) is the brown tumor also known as osteoclastoma. It consists in cystic and fibrotic changes of the bone. Tumors affect ribs, pelvis, long bones, extremities. Brown tumor lesions occur in less than $2 \%$ of patients with 
$\mathrm{HPT}^{2}$, more often in primary HPT, but also in severe secondary HPT, as well as in renal failure patients, on hemodialysis stage.

We present a patient who was admitted in our hospital with a fracture on a brown tumor and in whom we diagnosed a PTC with associated HPT along with another brown tumor on the left ischion. For the imaging diagnosis of PTC, ultrasound examination of the neck is very useful. Tc sestamibi scintigraphy and computed tomography may help in diagnosis and evaluation of presurgery extension, or in documenting recurrencies. The treatment of PTC consists in extensive resection (ipsilateral thyroid lobectomy, isthmectomy, tracheal skeletonization), which confers a much better prognosis than simple parathyroidectomy. Neither radiotherapy nor chemotherapy is effective in managing PTC. In cases with high serum calcium, non-responsive to surgery, or in advanced metastatic disease, an option would be the new drugs recently approved which inhibit the release of PTH by targeting the calcium sensing receptor.

\section{Case presentation}

Our patient is a 69 year-old man, recently seen in the orthopedic clinic, for an old fracture of the proximal third of the left femur. The fracture was on pathological bone, revealed at radiography. The femur bone biopsy done by the orthopedic department documented infiltration of bone marrow with fibroblastic tissue, increased osteoblastic activity (Figure 1a), deposition of hemosiderin, scattered multinucleated giant cells (Figure 1b), findings corresponding to a brown tumor of the shaft of the femur. At admission in our department, the patient was bedridden, passive, in a state of profound confusion. He was weak, emaciated, and unable to stand up. Muscle weakness had begun in the last few months, initially moderate, but weakness became progressively worse. Two moths prior to the presentation in our department, after a minimal trauma, a femur fracture occurred. In the previous month, the patient had anorexia, constipation, nausea, abdominal and bone pains, polyuria and polydipsia. The patient was also suffering from bilateral renal lithiasis being in the evidence of the urological department. The neurological examination, in our department, showed muscular deficit of superior and inferior limbs, with hypoactive deep tendon reflexes and muscle atrophy. There were neither sensory anomalies, nor cranial nerves deficit. Body temperature was normal.

Bone radiographies revealed multiple lithic expansive lesions with evidence of an old pathological fracture of the left femur (Figure 2a) and similar indolent lesion on the left ischium (Figure 2b). Generalized osteopenia and osteoporosis were documented. Whole body CT infirmed the existence of a primary neoplasm. Blood values for CA 15-3, CEA, CA 125 and PSA were in normal range. Thyroid hormones values were also normal. Laboratory examination documented a high total serum Ca level (up to $11 \mathrm{mEq} / 1$, normal range up to $5 \mathrm{mEq} / \mathrm{l}$ ) with a high ionized Ca. The serum alkaline phosphatase was 416U/L. Serum parathormone level was $120 \mathrm{pg} / \mathrm{l}$ (normal range up to $20 \mathrm{pg} / \mathrm{l}$ ). Serum potassium and serum sodium concentrations were in reference range. Electrocardiogram showed a ventricular rate of 100 beats per minute, sinus rhythm.

Ultrasound examination of the neck documented one very enlarged parathyroid gland with a big tumor growing deeper into adjacent tissues, hyperechoic, with irregular edges. A PTC with primary hyperparathyroidism was diagnosed.

The treatment of our patient consisted in hydration, associated with high doses of diuretics and diphosphonates administration. After having the serum calcium in normal range, with the correction of all neurologic symptoms and the amelioration of the general state, the patient was directed to the surgical department for intervention. Surgery consisted in extensive resection (ipsilateral thyroid lobectomy with removal of the parathyroid glands, isthmectomy, tracheal skeletonization). A large, white, hard mass invading the parathyroid gland was documented at surgery. As the recurrent laryngeal nerve was also involved, an en bloc resection, including the nerve was made by the surgical team without any lymph node dissection. An adenocarcinoma was diagnosed at histology in the enlarged parathyroid gland. Microscopic examination showed mitotic figures, fibrous trabeculae, capsular and blood vessel invasions. The patient is now recovering after surgery, and the serum PTC and calcium are normalizing. The brown tumors necessitated no additional surgical treatment yet. 


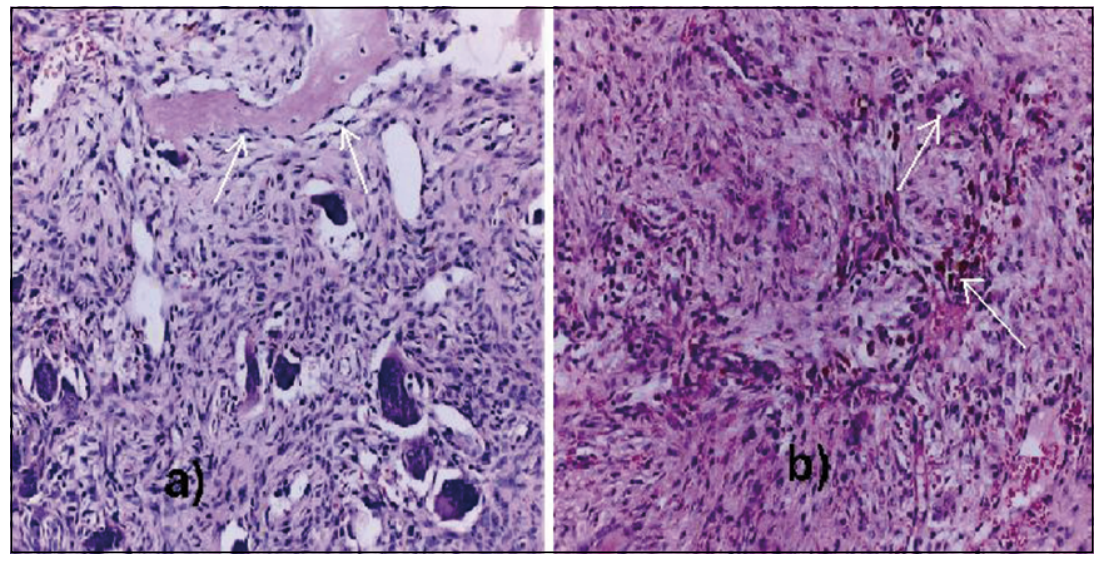

Figure 1.

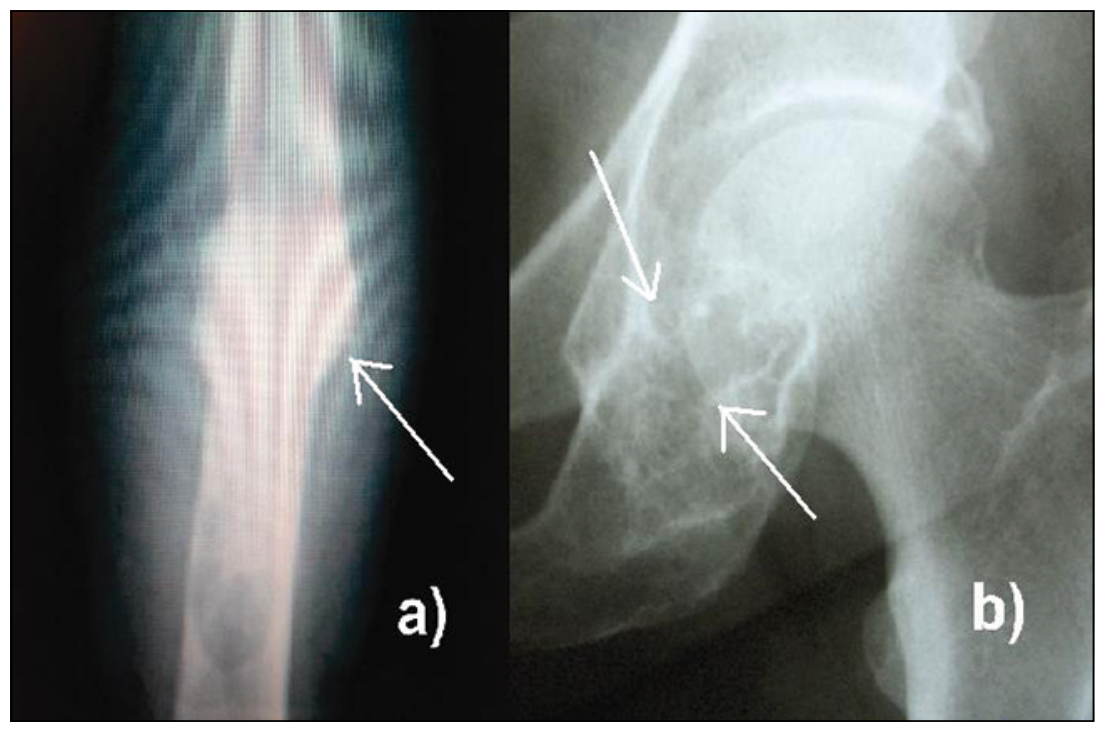

Figure 2.

\section{Discussion}

In patients with PTC and primary HPT, excessive parathormone secretion increases bone osteoclastic activity. Ten to twenty percent patients with primary HPT have bone disease ${ }^{1}$. Brown tumor, also known as osteoclastoma or osteitis fibrosa cystica consists in a bone cyst, involving the long bones, the extremities, the ribs and pelvis, the maxillary and mandible, the skull and even the spine $^{2}$. Although they may mimic bone metastases, osteolytic lesions may break the cortex, but do not generate periostal reaction and do not invade adjacent tissues. Brown tumor is considered a benign tumor, belonging to giant cell tumors.
Fibrous tissue replacing the bone is mixed with multinucleated giant cells and hemorrhagic foci (accumulation of hemosiderin in macrophages gives the name of the tumor) ${ }^{2}$. The cyst may grow, generate pain or secondary fractures. A MR study revealed that brown tumors may be of three consistencies: solid, cystic or mixed solid and cystic ${ }^{3}$. The majority of brown tumors are secondary to parathyroid adenoma, a smaller proportion secondary to parathyroid primary hyperplasia, and rarely as a cause of carcinoma. Generally, one of the parathyroid glands is hyperfunctional, the other being inhibited. To our knowledge, our case is one of the very rare with multiple brown tumors in a patient with PTC and primary HPT. 
Parathyroid carcinoma (PTC) is a very rare tumor, with an incidence between $0.35-0.57$ in 1 million individuals representing $0.005 \%$ of malignant tumors ${ }^{4}$. The incidence of PTC is almost equally distributed between males and females, the mean age at diagnosis being in the fifth decade ${ }^{5}$.

The majority of PTC are secretory and brown tumors have been described in such cases as a result of HPT. Fractures occur in almost 90\% of untreated patients. Our patient also suffered from bilateral renal calculi, which is second most often encountered complication. It is appreciated that up to one forth of cases of primary HPT have renal lithiasis ${ }^{1}$. Renal calculi are secondary to increased reabsorption of calcium in kidneys and phosphaturia. Although renal disease occurs equally in PTC and benign hyperparathyroidism, simultaneous renal and bone disease shows rather malignant than benign parathyroid disease (occurring in half of patients with PTC) $)^{6-8}$. Gastrointestinal ulcer, anemia, pancreatitis also occur more frequently in malignant parathyroid disease ${ }^{9}$.

A new serum marker in PTC is considered the human chorionic gonadotropin elevated in plasma and urine in patients with this malignant tumor ${ }^{10}$. Tc sestamibi scintigraphy and computed tomography may help in diagnosis, preoperatory extension evaluation, or in documenting recurrencies ${ }^{1,12}$. Although of diagnostic utility, we were reluctant in practicing a biopsy in our patient since it may lead to rupture of the capsule with local and distant dissemination ${ }^{13,14}$.

The endocrinological treatment in our patient consisted in extensive resection (ipsilateral thyroid lobectomy with removal of parathyroids, isthmectomy, tracheal skeletonization). This intervention has a much better prognosis than simple parathyroidectomy ${ }^{15}$. The surgical team practiced an "en bloc" resection including the recurrent laryngeal nerve, who was also involved. Intraoperative PTH monitoring might be very useful. According to some authors, serum calcium will be within normal limits for more than 6 months if during operation the PTH drops more than $50 \%{ }^{16}$. In this case, the histopathologic examination was quite relevant.

After parathyroidectomy brown tumors tend to regress. Radiotherapy and chemotherapy are not effective in PTC management.

High serum calcium may be managed on short term with diuretics, intravenous fluids, glucosteroids, mithramycin, dialysis, parenteral biphosphonates. New drugs like cinacalcet, NPS R-467 (a phenylalkylamine) and R-568, efficient in different clinical trials with minimum side effects, might be used in cases with high serum calcium, not responsive to surgery, or in advanced metastatic disease ${ }^{17}$. Anti PTH antibodies (produced by immunization with bovine PTH peptides) and denosumab, are being evaluated lately in clinical trials in patients with $\mathrm{PTC}^{18}$.

After parathyroidectomy the patient is placed on calcium and vitamin D therapy.

Intensive monitoring is necessary in the first 2 years after surgical intervention, as the majority of recurrences appear in the first 3-4 years, but also on longer term, as relapses have been reported even at 10 to 15 years after operation ${ }^{19}$. Recurrences appear in a third-up to a half of patients operated for PTC. Very poor prognosis has early recurrence, as in general they cannot be cured. Five year survival rate is 50 to 80 percent. Age, unsuccessful first surgery, histopathological type (aneuploidy, increased mitosis index) are poor prognostic factors ${ }^{20}$.

\section{References}

1. Ekram U, Mehtab A, Syed AA, Navneet R. Primary hyperparathyroidism having multiple Brown tumors mimicking malignancy. Indian J. of Endocr. and Metab. 2012; 16 (6): 1040-2.

2. Sabatier AD, Gondouin B, Bouvier C, Bataille S, Berland Y, Brunet P. Brown tumor: still an old disease? Kidney International 2011; 80 (10): 1110.

3. Hong WS, Sung MS, Kim JY, Park SW, Lee KH, Lim HW et al. Emphasis on the MR imaging findings of brown tumor: a report of five cases. Skeletal Radiol 2011; 40 (2): 205-13. Epub 2010 Jun 13.

4. Hundahl SA, Fleming ID, Fremgen AM, Menck HR. Two hundred eighty-six cases of parathyroid carcinoma treated in the U.S. between 1985-1995: a National Cancer Data Base Report. The American College of Surgeons Commission on Cancer and the American Cancer Society. Cancer 1999; 86 (3): 538-44.

5. Holmes EC, Morton DL, Ketcham AS. Parathyroid carcinoma: a collective review. Ann Surg 1969; 169 (4): 631-40.

6. Hundahl SA, Fleming ID, Fremgen AM, Menck HR. Two hundred eighty-six cases of parathyroid carcinoma treated in the U.S. between 1985-1995: a National 
Cancer Data Base Report. The American College of Surgeons Commission on Cancer and the American Cancer Society. Cancer 1999; 86 (3): 378-80.

7. Shane E. Clinical review 122: Parathyroid carcinoma. J Clin Endocrinol Metab 2001; 86 (2): 485-93.

8. Busaidy NL, Jiménez C, Habra MA, Schultz PN, ElNaggar AK, Clayman GL, et al. Parathyroid carcinoma: a 22-year experience. Head Neck 2004; 26 (8): 716-26.

9. Marcocci C, Cetani F, Rubin MR, Silverberg SJ, Pinchera A, Bilezikian JP. Parathyroid carcinoma. J Bone Mineral Res 2008; 23 (12): 1869-80.

10. Stock JL, Weintraub BD, Rosen SW, Aurbach GD, Spiegel AM, Marx SJ. Human chorionic gonadotropin subunit measurement in primary hyperparathyroidism. J Clin Endocrinol Metab 1982 ian; 54 (1): 57-63.

11. Hara H, Igarashi A, Yano Y, Zashiro T, Ueno E, Aiyoshi $\mathrm{Y}$, et al. Ultrasonographic features of parathyroid carcinoma. Endocr J 2001; 48 (2): 213-7.

12. Clark P, Wooldridge T, Kleinpeter K, Perrier N, Lovato J, Morton K. Providing optimal preoperative localization for recurrent parathyroid carcinoma: A combined parathyroid scintigraphy and computed tomography approach. Clin Nucl Med 2004; 29 (11): 681-4.

13. Spinelli C, Bonadio AG, Berti P, Materazzi G, Miccoli P. Cutaneous spreading of parathyroid carcinoma after fine needle aspiration cytology. J Endocrinol Invest
2000; 23 (4): 255-7.

14. Adam MA, Untch BR, Olson JA. Parathyroid Carcinoma: Current Understanding and New Insights into Gene Expression and Intraoperative Parathyroid Hormone Kinetics. Oncologist 2010; 15 (1): 61-72.

15. Koea JB, Shaw JH. Parathyroid cancer: Biology and management. Surg Oncol 1999; 8 (3): 155-65.

16. Solórzano CC, Carneiro-Pla DM, Lew JI, Rodgers SE, Montani R, Irvin GL 3rd. Intra-operative parathyroid hormone monitoring in patients with parathyroid cancer. Ann Surg Oncol 2007; 14 (11): 3216-22. Epub 2007 sep 6.

17. Silverberg SJ, Rubin MR, Faiman C, Peacock M, Shoback DM, Smallridge, et al. Cinacalcet hydrochloride reduces the serum calcium concentration in inoperable parathyroid carcinoma. J Clin Endocrinol Metab 2007; 92 (10): 3803-8. Epub 2007 jul 31.

18. Bradwell AR, Harvey TC. Control of hypercalcaemia of parathyroid carcinoma by immunisation. Lancet 1999; 353 (9150): 370-3.

19. Wang CA, Gaz RD. Natural history of parathyroid carcinoma. Diagnosis, treatment, and results. Am J Surg 1985; 149 (4): 522-7.

20. Sandelin K, Auer G, Bondeson L, Grimelius L, Farnebo LO. Prognostic factors in parathyroid cancer: A review of 95 cases.World J Surg 1992; 16 (4): 724-31. 